\section{Offshore refuge for US students}

Washington

THE 650 students at St George's University School of Medicine - whose presence on Grenada was used, at least for a few days, as justification for the United States invasion of the tiny Caribbean island - are members of a rather mediocre group of perhaps as many as 15,000 US citizens who are studying medicine abroad after having been rejected by US schools.

During the 1970s, more than a dozen such medical schools were set up in Mexico, the Caribbean and the Philippines to cater for such people. The schools are not accredited, have no entrance requirements other than ability to pay the tuition fees, and are attended overwhelmingly by North Americans.

St George's differs from other such schools only in the relative success of its students in returning to medical practice in the United States. Of the 218 St George's students who last year took the test set by the Education Commission for Foreign Medical Graduates (ECFMG) - a requirement for foreign-trained Americans wishing to obtain residencies at US hospitals - 79 per cent passed. The average success rate on the test is only 30 per cent.

But like five other "offshore" medical schools investigated by Congress's General Accounting Office in 1980, St George's

\section{Soviet aid in Grenada}

THE Soviet Government has been planning a major technical aid programme intended to make Grenada self-sufficient in food, Pravda reported last week. A feature article by a hydraulic engineer, $S$. Sergeev, who visited Grenada last winter, gave a glowing report of the intentions of the Soviet Ministry of Land Improvement and Water Management to help the Grenadians to design canals and reservoirs, sink artesian wells, construct irrigation works and plan the lay-out of fields.

The soil could thus be made to yield several harvests a year, Sergeev explained, and the Grenadians would then be able to "supply themselves with foodstuffs which are at present imported from other countries".

Sergeev did not explain how this assistance would be repaid. Soviet aid programmes to Third World countries do not normally take the form of free gifts which would "pauperize" the recipients except in cases of disaster relief. The usual pattern, when Soviet know-how is used to develop a country's mineral or agricultural resources, is for the beneficiary country to repay the investment over a protracted period with a proportion of the increased production made possible by that aid.

Vera Rich was criticized for having inadequate clinical training, poor laboratory facilities and too few qualified teachers. And, true to its type, St George's was founded in 1976 by an American entrepreneur - Charles Modica, himself a rejected medical school applicant. Modica, who is $\mathbf{3 6}$ years old, continues to serve as "chancellor" of the school.

Many of the schools were founded at a time when applications to US medical schools were rising sharply. For some $\mathbf{5 0}$ years until the 1970 s, applications had held steady at a rate of two for each available place. During the 1970 s, that rose to three for each place. A congressional amendment requiring US medical schools that received federal support to admit a percentage of US students who had completed two years at offshore schools

\section{Women in science}

\section{Rehovot}

SEX discrimination against academic women has now become an issue in Israel, where, as elsewhere, women academics are a rare breed. Here academic women tend to work in the natural sciences and medicine - at the Hebrew University of Jerusalem, for example, there are nineteen women in the natural sciences and medicine but only four in the social sciences and humanities. Dr Galia Golan, a fierce feminist and the first professor of political science at the Hebrew University, has a cynical explanation: in the natural sciences there are objective criteria for measuring achievement but in the humanities "subjectivity is a major factor", while promotion committees are predominantly male. Professor Golan, who is seeking to increase the number of women in senior academic positions, claims "four children and four books" to her credit, but has throughout her career forgone sabbatical leave abroad because her husband is a physician in private practice.

Sabbatical visits overseas, more necessary in the natural sciences than in other fields, are a constant difficulty. One woman scientist at the Weizmann Institute says that her recent two years at a British university was a "hardship for the whole family". She took her two daughters with her, but her husband joined them only for brief visits. Yet, she says, scientists who "are serious" about their work have no choice but to go abroad.

The Weizmann women are an extraordinarily homogeneous group according to Dr Hadassah Horn of the Hebrew University. Almost all earned their PhD degrees at about the age of 30 , and have spent five years reaching the highest nontenured rank of senior researcher. With also increased the popularity of the schools for rejected US applicants. The Caribbean and Mexican schools also benefited from a decision by Italy - once a popular choice for rejected US students - to require a proficiency in Italian.

Since then, however, Congress has repealed the "Guadalajara" amendment and applications to US medical schools have fallen to the previous 2 to 1 level. The popularity of the offshore schools may wane further with the forthcoming revision of the ECFMG test due next spring. The test, which has been criticized for setting a standard below that of the national board examinations that US medical students must pass, will be toughened and will add, for the first time, a requirement that students should demonstrate their practical proficiency.

The very need for the offshore medical schools has increasingly been called into question by recent government projections of a surplus of physicians in the United States.

\title{
No home from home in Israel
}

one exception, all have children.

On past form, further advancement to a tenured post will be difficult. Women are a quarter of senior researchers at the institute but only 7 per cent of associate professors and 4 per cent of full professors. Much the same is true at the Hebrew University, where women account for no less than 65 per cent of those in non-tenure track positions but for only 21 per cent of lecturers, 13 per cent of senior lecturers, 12 per cent of associate professors and 6 per cent of full professors.

In Professor Golan's opinion, the explanation for this imbalance is that the criteria for academic advancement, set by men, do not fully take account of women's need to miss time in their late 20 s and early $30 \mathrm{~s}$, when they have young children to look after. Professor Golan is also annoyed by lesser issues. It has finally been agreed that female academics should be allowed to stay at work until they are 65 , but she says there is still discrimination against women in conditions of employment. She wants women to be given priority when the universities are once again able to recruit staff, and says there will be no danger that women would take priority over more highly qualified men because "there are plenty of women just waiting for the opportunity"'.

Not all women academics agree. Professor Ester Samuel-Cahn of the Hebrew University thinks the shortage of women in senior academic posts is a consequence of women's deliberate choice of family responsibilities. Her colleague Professor Alice Shalvi, mother of six children, agrees that academic women must make a choice between "neglecting their children and working".

Nechemia Meyers 